\title{
ПРАВО
}

УДК 342.25

Боярський Олександр Олександрович,

Кандидат юридичних наук, докторант Інституту законодавства

Верховної Ради України, суддя Білгород-Дністровського міського суду Одеської області. ORCID: https://orcid.org/0000-0003-3725-1703

\section{ВИДИ ТЕРИТОРІАЛЬНИХ ГРОМАД В ЯКИХ ФУНКЦІОНУС ЛЮДИНА - ЧЛЕН ГРОМАДИ}

Анотація. Стаття присвячена дослідженню питання участі людини як члена громади у існуванні та функціонуванні територіальної громади. Стаття містить характеристику видів територіальних громад, а також їх загальні ознаки. У статті визначено спосіб функціонування людини як члена громади у територіальній громаді.

Ключові слова: територіальна громада, види територіальних громад, людина як член громади, функціонування територіальної громади.

Abstract. The article is devoted to the study of human participation as a member of the community in the territorial community. The article contains a description of the types of territorial communities, as well as their general features. The article defines the way a person functions as a member of the community in the territorial community. 


\section{ПРАВО}

Keywords: territorial community, types of territorial community, a person as a member of the community, the functioning of the territorial community.

Постановка проблеми. У процесі розвитку демократичної правової державності в Україні та посилення її євроінтеграційного курсу питання функціонування територіальної громади виступають не тільки важливою частиною виконання міжнародних угод у контексті організаційного і організаційно-правового супроводження і нормативноправового забезпечення необхідної децентралізації публічної влади, місцевого самоврядування в Україні загалом, а ї набуття такою локальною громадою відповідної і належної, реальної та такої, що є спроможною, правосуб'єктності. Ще більш важливим постає питання визначення участі та обізнаності у можливості людини приймати участь як член територіальної громади для реалізації своїх екзистенційних настанов - інтенцій, потреб, устремлінь, інтересів, атитюдів, бо саме від цього залежить цінність такої громади в межах локального соціуму та в умовах місцевого самоврядування, первинним суб' єктом якого і виступає така громада (див. ст. 140 Конституції України [1]).

Тож, постає необхідність у дослідженні питання участі людини у територіальній громаді, i, відповідно до наведеної контекстуалізації визначенні: а) поняття «територіальна громада»; б) видів територіальних громад в Україні та в) механізмів і способів участі людини у функціонуванні тієї чи іншої територіальної громади.

Стан дослідження. Питанню особливостей функціонування територіальної громади та участі у цьому функціонуванні людини присвятили увагу у своїх наукових статтях та інших наукових роботах такі вітчизняні науковці як: Авер`янов В., Андресюк Б., Андрійко О., Баймуратов М. О., Баймуратов М. М., Батанов О., Баштанник В., Біленчук П., Биков О., Борденюк В., Бориславська О., Воронов М., Давидов Р., 


\section{ПРАВО}

Демиденко В., Калиновський Б., Кампо В., Ковтун I., Колодій А., Корнієнко М., Кулик Т., Куйбіда В., Литвиненко I., Мартиненко П., Мішина Н., Пархоменко В., Пелих Н., Солоненко О., Шкабаро В., Щебетун I. та інші.

Мета статті полягає у дослідженні загальної характеристики інструментів і способів функціонування територіальної громади в Україні, видів територіальних громад в Україні та участі людини у функціонуванні територіальної громади.

Виклад основного матеріалу. Місцеве самоврядування в Україні має давні традиції. Так, іще за часів Київської Русі набуло розвитку громадівське самоврядування, в основу якого було покладено виробничу й територіальну ознаки - громади, які інституціоналізувалися на основі екзистенційних настанов, структуризувалися завдяки необхідності локального соціального управління i вирішення необхідних питань існування і самоврядовувалися для формалізації колективістських засад людської спільноти, формувалися переважно за виробничою (громади купців, ремісників тощо) або територіальною ознаками (сільська, міська та регіональна громади).

Територіальне громадівське самоврядування базувалося на звичаєвому праві та знаходило свій прояв у народних вічах. Для вічової організації управління характерним був більш-менш чіткий розподіл повноважень між вічем та обраними на ньому органами і посадовими особами [5].

Новітня історія місцевого самоврядування в Україні почалася після прийняття 7 грудня 1990 р. Закону Української РСР «Про місцеві ради народних депутатів Української РСР та місцеве самоврядування», в якому місцеве самоврядування визначалося як «територіальна самоорганізація громадян для самостійного вирішення безпосередньо або через державні і громадські органи, які вони обирають, усіх питань 


\section{ПРАВО}

місцевого життя, виходячи 3 інтересів населення, на основі законів Української РСР та власної фінансово-економічної бази» [2]. Прийняття Закону стало першим кроком до відновлення місцевого самоврядування в Україні, дозволило закріпити ряд його основоположних принципів, пов'язаних із правовою й фінансовою автономією [7].

Наступним кроком стало прийняття 26 березня 1992 р. нової редакції Закону (в новій редакції він мав назву Закон України «Про місцеві ради народних депутатів та місцеве i регіональне самоврядування» [3]), в якому місцеве та регіональне самоврядування закріплювалось як основа демократичного устрою влади в Україні. Місцеве та регіональне самоврядування розглядалось як територіальна самоорганізація громадян для самостійного вирішення безпосередньо або через органи, яких вони обирають, усіх питань місцевого життя в межах Конституції України, законів України та власної фінансовоекономічної бази, а регіональне самоврядування як територіальна самоорганізація громадян для вирішення безпосередньо або через органи, яких вони утворюють, питань місцевого життя в межах Конституції України та законів України. При цьому територіальною основою місцевого самоврядування визначалися сільрада, селище, місто, а регіонального самоврядування - район, область [8].

3 прийняттям Конституції України 1996 р. місцеве самоврядування отримало конституційний статус, стало однією із важливіших засад конституційного ладу України (див. ст. 7 Конституції України) [1].

21 травня 1997 р. було прийнято Закон України «Про місцеве самоврядування в Україні» [4], який відповідно до Конституції України визначає систему та гарантії місцевого самоврядування в Україні, засади організації та діяльності, правового статусу і відповідальності органів і посадових осіб місцевого самоврядування. 


\section{ПРАВО}

Згідно ст. 6 Закону України «Про місцеве самоврядування в Україні», первинним суб'єктом місцевого самоврядування, основним носієм його функцій і повноважень є територіальна громада села, селища, міста, яка може утворювати єдині органи місцевого самоврядування та обирати відповідно сільського, селищного, міського голову. Тож, виходячи 3 даного положення, можна зробити висновок, що територіальна громада може утворити орган місцевого самоврядування, але не є ним [6].

До системи місцевого самоврядування України слід віднести територіальну громаду, сільську, селищну, міську ради; сільського, селищного, міського голову; старосту; виконавчі органи сільської, селищної, міської ради; районні та обласні ради, що представляють спільні інтереси територіальних громад сіл, селищ, міст; органи самоорганізації населення [7].

Отже, видова характеристика громад має не тільки наукове, але й практичне значення. Кожний з видів територіальних громад має свої соціологічні, економічні культурологічні характеристики. За дією механізмів захисту інтересів громадян як членів територіальних колективів розрізняють:

- основні (місто, село, селище, район);

- факультативні (мікрорайон, квартал, вулиця, будинок тощо).

Розходження між тими групами територіальних колективів полягає в тому, що органи самоврядування першої групи - місцеві ради, які засновують свою діяльність на широких повноваженнях, закріплених у чинних законах, є обов'язковими. Крім того, існування таких органів публічної влади обгрунтовується ще низкою характерологічних рис локального характеру, а саме:

- по-перше, вони, формуються безпосередньо членами територіальних громад-жителями; 


\section{ПРАВО}

- по-друге, саме це дає можливість вимагати жителю-члену ТГ, щоб така місцева рада діяла від його імені та в його інтересах;

- по-третє, саме така рада та їі виконавчі органи повинні створити в рамках такої територіальної громади соціально-правовий простір в якому можуть: а) виникати у ऑiі членів інтенції, б) ідентифікуватися і продукуватися устремління і потреби, в) проявлятися інтереси, г) формуватися атитюди;

- по-четверте, саме органи публічної влади, що функціонують на рівні територіальної громади повинні сформувати нормативно-правовий простір в якому буде реалізовуватися конституційно-правовий статус людини, тобто її права і обов'язки.

Звідси, можна стверджувати, що територіальні громади первинного рівня $є$ тими громадами, в яких людини повністю реалізує своє право на місцеве самоврядування, включаючи, насамперед, реалізацію своїх екзистенційних інтересів та інших потреб, обумовлених здійсненням людиною свого життєвого циклу в межах територіальної спільноти, що реалізується в умовах повсякденності, переважно при ординарному здійсненні державності.

Своєю чергою, діяльність факультативних територіальних колективів (громад) є врегульованою законодавством України, зокрема, Законом України «Про органи самоорганізації населення» від 11.07.2001 p., Законом України «Про об'єднання співвласників багатоквартирного будинку» від 29.11.2001 р., іншими законодавчими актами, проте вони носять факультативний, необов'язковий характер [7]. Тут треба звернути увагу, що не дивлячись на відповідну нерозвиненість цього рівня територіальних громад, що виникають переважно і буквально тільки по місцю проживання людей (квартал, вулиця, мікрорайон, будинок тощо), вони також відіграють відповідну роль в активізації людини в сфері місцевого самоврядування, але саме тут, на нашу думку, важливим 


\section{ПРАВО}

елементом активізації функціонування такої громади виступають внутрішня мотивація кожної людини-жителя на участь у місцевому самоврядуванні та рівень іiі соціальної активності, що залежить від власних рис характеру кожної людини, iї ідеологічних настанов та якісного рівня іiї соціалізації.

За просторовою межею діяльності територіальних колективів (громад) виділяють:

- територіальні колективи в межах населеного пункту або базових, «природних» територій (місто, село, селище);

- територіальні колективи в межах адміністративнотериторіального колективу, «штучних» територій (райони, області, АР Крим);

- територіальні колективи в межах великих економічних районів.

Треба зазначити, що в рамках таких територіальних громад роль людини проглядається вельми слабо, враховуючи асоційований рівень таких громад, що в основному носять інтегративно-синтетичний характер та створюються фактично на теоретично-нормативному рівня для представництва колективних інтересів громад першого (базового) рівня (села, селища, міста) на неіснуючому для фізичного існування людини рівні (район, область). Разом з тим, з позицій захисту колективних інтересів членів територіальних громад тут має місце простір для діяльності депутатів районних i обласних рад, представників інституцій громадянського суспільств, включаючи представників політичних партій та рухів. Однак, на нашу думку, представництво людини в системі місцевого самоврядування на цьому рівні $\epsilon$ апріорі неповним, фактично декларативним та алогічним, враховує пріоритет колективних інтересів, що лежить в діяльності таких асоційованих територіальних колективів (громад). 


\section{ПРАВО}

Конституція України (ч. 1, ст. 140) і профільне законодавство України про місцеве самоврядування закріплює таку систему територіальних колективів:

- територіальна громада села або добровільне об'єднання в сільську громаду мешканців кількох сіл;

- територіальна громада селища;

- територіальна громада міста.

Згідно статей 12 та 14-1 Закону України «Про місцеве самоврядування в Україні» сільський, селищний, міський голова $\epsilon$ головною посадовою особою територіальної громади відповідно села (добровільного об'єднання в одну територіальну громаду жителів кількох сіл), селища, міста, а староста є виборною посадовою особою місцевого самоврядування, що обирається жителями села, селища (сіл, селищ), розташованого на території відповідного старостинського округу, на основі загального, рівного, прямого виборчого права шляхом таємного голосування в порядку, визначеному законом, i здійснює свої повноваження на постійній основі. Дані норми також не містять достатньо ознак для того, щоб охарактеризувати сільського, селищного, міського голову чи старосту як самостійний орган місцевого самоврядування, хоча наявність у нього представницького потенціалу, враховуючи виборний характер формування таких інституцій, не викликає сумніву.

Беручи до уваги положення Закону України «Про добровільне об’єднання територіальних громад» від 5 лютого 2015 року [9], особливого значення набуває громадський контроль як система контролю саме над органами місцевого самоврядування.

Такий контроль за діяльністю органів місцевого самоврядування $\epsilon$ важливою формою реалізації демократії та способом залучення громадян до управління суспільством та державою, а крім того, і ефективною Соціальний калейдоскоп $\quad 1 / 2020$ 


\section{ПРАВО}

формою залучення жителів-членів територіальних громад, що є не тільки громадянами патримоніальної держави, а і іноземцями, біженцями тощо, тобто фізичними особами, що мають різний правовий стан.

Громадський контроль як вид соціального контролю здійснюється об'єднаннями громадян та окремими громадянами (правильніше стверджувати - жителями-членами територіальної громади), а також $є$ функцією громадянського суспільства, тому виступає способом залучення населення до управління суспільством (в тому числі i локальним) та державою, а найголовніше - $є$ важливою формою реалізації демократії, оскільки дає можливість населенню і кожному жителю-члену територіальної громади брати участь у вирішенні суспільних справ, активно впливати на діяльність органів місцевого самоврядування.

Слід відзначити, що такі форми громадського контролю, як громадські слухання, громадська експертиза, створення громадських рад, а також участь громадськості у роботі колегіальних органів при органах влади взагалі можуть надати впевненості громаді щодо захисту власних інтересів, ефективності та результативності використання державних ресурсів, що ӥй надані у користування. Причому процедуру здійснення громадського контролю обов'язково слід прописувати у статутах територіальних громад, які приймаються місцевими радами представницькими органами місцевого самоврядування.

Законом України «Про місцеве самоврядування в Україні» за територіальними громадами закріплено велике коло прав. Однак, незважаючи на широке коло прав, які закріплені за територіальною громадою, іiі безпосередня участь у суспільно-політичному житті, контроль за органами місцевого самоврядування обмежується переважно виборчими функціями: формування виборних органів місцевого самоврядування (сільських, селищних, міських, районних у містах, 


\section{ПРАВО}

районних, обласних рад); обрання виборних посадових осіб місцевого самоврядування (сільського, селищного, міського голови). Але вибори, виступаючи періодичною формою здійснення контрольних повноважень, все ж не гарантують повноцінного контролю громади за діяльністю органів та посадових осіб місцевого самоврядування.

Тут слід зазначити, що діяльність місцевих рад та їх виконавчих органів у розумінні телеологічних настанов здійснюється від імені та в інтересах відповідних територіальних громад, тому тує $є$ в наявності досить чіткий методологічно-процесуальний зв'язок, що виникає в процесі реалізації зазначених прав і інтересів. Ця проблематика є досить актуальною, бо більшість територіальних громад та їх членів-жителів фокусують і конкретизують свої потреби і інтереси через формування найважливіших питань місцевого значення, що $є$ основоположним об’єктом як самого інституту місцевого самоврядування держави, так і діяльності органів місцевого самоврядування. Серед таких питань місцевого значення пріоритетними визначаються питання існування, функціонування та розвитку житлово-комунального господарства та місцевого бюджету, що фактично є постійними і обов'язковими для розгляду на громадських слуханнях [8]. Характерним тут є, що такі питання виникають, формуються i продукуються саме в межах територіальної громади та $є$ уособленням індивідуальних інтенцій, устремлінь, потреб, інтересів, атитюдів членів такої громади. Звідси, саме громада виступає соціальним простором в якому народжуються майбутні основоположні об'єкти соціальної і нормативної регламентації i регулювання місцевого самоврядування. Причому необхідно розуміти, що, наприклад, питання житлово-комунального господарства - це переважно питання отримання жителями-членами територіальних громад якісних муніципальних послуг, що лежать в основі самоідентифікації людини як члена локальної спільноти, що діє в умовах 


\section{ПРАВО}

локальної демократії, більш того, - вони скеровані не тільки для задоволення його індивідуальних екзистенційних інтересів, а також сприяють виникненню і підвищенню у такого жителя індивідуальної, групової і колективної мотивації до участі у місцевому самоврядуванні.

Дослідник Борденюк В. I. зазначає, що головні повноваження місцевого самоврядування, що містяться в ч. 1 ст. 143 Конституції України, вона адресує територіальним громадам та утворюваним ними органам місцевого самоврядування, під якими треба розуміти відповідні ради, а не їх виконавчі органи, оскільки останні безпосередньо територіальною громадою не утворюються [5, с. 134].

Необхідно наголосити, що ані в Конституції України, ані в чинному законодавстві не визначено територіальної основи місцевого самоврядування, тобто території, в межах якої територіальна громада здійснює місцеве самоврядування. Тому досить проблематичною уявляється реалізація принципу незмінності територіальних кордонів місцевих влад (див. ст. 5 Європейської хартії місцевого самоврядування 1985 p. [10]).

Сьогодні досить обмеженими в Україні $€$ можливості територіальних громад самостійно визначати свої адміністративні структури (принцип, закріплений у ст. 6 Європейської хартії місцевого самоврядування), вони досить вичерпано визначені централізовано - в профільному Законі України «Про місцеве самоврядування в Україні».

Крім того, в містах Києві та Севастополі ще не створено власних виконавчих структур місцевого самоврядування, а їхні функції покладено на відповідні місцеві державні адміністрації. Вважаємо, що зазначене, суттєво обмежує реалізацію принципу організаційної автономності.

Висновки. Згідно ст. 6 Закону України «Про місцеве самоврядування в Україні», первинним суб'єктом місцевого самоврядування, основним носієм його функцій $\mathrm{i}$ повноважень $\epsilon$ 


\section{ПРАВО}

територіальна громада села, селища, міста, яка може утворювати єдині органи місцевого самоврядування та обирати відповідно сільського, селищного, міського голову.

Конституція України (ч. 1, ст. 140) і профільне законодавство України про місцеве самоврядування закріплює таку систему територіальних колективів:

- територіальна громада села або добровільне об'єднання в сільську громаду мешканців кількох сіл;

- територіальна громада селища;

- територіальна громада міста.

Саме на наведених рівнях людина-житель i одночасно член територіальної громади може продукувати i реалізовувати свої екзистенційні настанови, сполучаючи це на основі синергії з участю в місцевому самоврядуванні

Законом України «Про місцеве самоврядування в Україні» за територіальними громадами закріплено велике коло прав. Однак, незважаючи на це, більшість 3 них, що закріплені за територіальною громадою, залишаються декларативними - а у підсумку, це не дає можливості сформувати належну, оптимальну, спроможну правосуб'єктність територіальної громади, яка надана їй Конституцією держави. Отже, безпосередня участь територіальної громади у суспільнополітичному житті, контроль за органами місцевого самоврядування обмежується переважно виборчими функціями: формування виборних органів місцевого самоврядування (сільських, селищних, міських, районних у містах, районних, обласних рад); обрання виборних посадових осіб місцевого самоврядування (сільського, селищного, міського голови).

Такий стан напряму впливає і на правовий статус людини в рамках

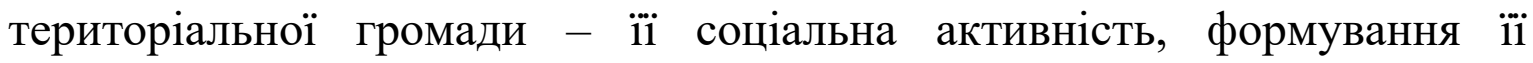




\section{ПРАВО}

мотивації до активної участі в місцевому самоврядування $є$ фактично заблокованими недоліками в нормативній регламентації та регулюванні реальних прав і можливостей територіальної громади, зокрема таких рівнів, де фактично функціонує людина - житель, а саме: на рівні сільської, селищної та міської територіальних громад.

Найбільш ефективну форму участі територіальної громади в локальному управлінні 3 метою активізації соціальних процесів в середині самої територіальної громади, 3 метою пожвавлення іiі функціонування, ми вбачаємо у активізації громадського контролю, який кожна людина-житель і одночасно член територіальної громади може здійснювати всіма дозволеними чинним законодавством способами, отже, впливаючи на життя територіальної громади особисто. Такий контроль за діяльністю органів місцевого самоврядування є важливою формою реалізації загальної і локальної демократії та ефективним способом залучення громадян до управління суспільством та державою.

Громадський контроль як вид соціального контролю здійснюється об’єднаннями громадян та окремими громадянами, а також є функцією громадянського суспільства, тому виступає способом залучення населення до управління суспільством та державою, а найголовніше - $€$ важливою формою реалізації демократії, оскільки дає можливість населенню, через участь у ньому окремих жителів та їх асоціацій, брати безпосередню участь у вирішенні суспільних справ, активно впливати на діяльність органів місцевого самоврядування.

\section{ПЕРЕЛІК ВИКОРИСТАНИХ ДЖЕРЕЛ}

1. Конституція України: прийнята на п’ятій сесії Верховної Ради України 28 червня 1996 року // Відомості Верховної Ради України. 1996. № 30. СТ. 141. 


\section{ПРАВО}

2. Про місцеві Ради народних депутатів та місцеве і регіональне самоврядування: Закон Української РСР від 7 грудня 1990 року // Відомості Верховної Ради УРСР. 1991. № 2. Ст. 5.

3. Про місцеві Ради народних депутатів та місцеве і регіональне самоврядування: Закон Української РСР від 7 грудня 1990 року // Відомості Верховної Ради УРСР. 1991. № 2. Ст. 5.

4. Про місцеве самоврядування в Україні: Закон України від 21 травня 1997 року // Відомості Верховної Ради УРСР. 1997. № 24. Ст. 170.

5. Борденюк В. I. Місцеве самоврядування та державне управління: конституційно-правові основи співвідношення та взаємодії : [монографія]. - К. : Парламентське вид-во, 2007. 576 с.

6. Барановська Т. М. Територіальні громади як первинний суб`єкт місцевого самоврядування та реалізації муніципальної політики/ Т. М. Барановська, О. Г. Остапенко// Державне управління: удосконалення та розвиток. 2015. № 10. С. 97. [Електронний документ]. - Режим доступу: http://www.dy.nayka.com.ua/?op=1\&z=909

7. Кащишин М. А. Державний контроль за реалізацією органами місцевого самоврядування повноважень в Україні та зарубіжних країнах // Форум права: електрон. наук. фахове вид. 2017. № 4. С. 93-98 [Електронний документ]. - Режим доступу: http://nbuv.gov.ua/jpdf/FP_index.htm_2017_ 4_16.pdf.

8. Кащишин М. А. Конституційно-правове закріплення повноважень органів місцевого самоврядування в Україні на основі зарубіжного досвіду. Конституційно-правові академічні студії. 2018. №2. С. 159-164 [Електронний документ]. http://constlegalstudies.in.ua/archive/2-2018/24.pdf

9. Про добровільне об'єднання територіальних громад: Закон України від 5 лютого 2015 року // Відомості Верховної Ради України. 2015. № 13. Ст. 91. 


\section{ПРАВО}

10. Європейська хартія місцевого самоврядування 1985 року. - Рада Свропи, 2015. 18 с. 